\title{
Buckling Analysis of Cantilever Laminated Hybrid Composite Plates using Finite Element and Statistical Methods
}

\author{
Savaş Evran ${ }^{1 *}$ iD \\ ${ }^{I}$ Canakkale Onsekiz Mart University, Canakkale Faculty of Applied Sciences, Department of Energy \\ Management, Canakkale, Turkey. \\ *sevran@comu.edu.tr
}

\begin{abstract}
In this study, the critical buckling load of hybrid composite plates with three layers was analyzed using numerical and statistical methods. Laminated hybrid composite plates were designed using glass-epoxy, boron-epoxy, carbon-epoxy, and metal. The outermost layers of the plates were modelled using fiber reinforced composite materials whereas the innermost layer of plates was created using Aluminum material (Al2024-T3). Numerical buckling behavior was calculated using finite element software ANSYS. Analysis of signal-to-noise ratio was utilized to decide the effects and optimal levels of the plates and their fiber orientation angles on buckling load. Analysis of variance at the $95 \%$ confidence level was employed to indicate the control factors which have significant effect on the buckling responses.
\end{abstract}

Keywords: Buckling, Hybrid composite, Finite Element, Taguchi Method.

\section{Özet}

Bu çalışmada üç tabakalı hibrit kompozit plakaların kritik burkulma yükü sayısal ve istatiksel metotlar kullanılarak analiz edilmiştir. Tabakalı hibrit kompozit plakalar cam/epoksi, bor/epoksi, karbon/epoksi ve metal kullanılarak dizayn edilmiştir. Plakaların en üst tabakaları fiberle güçlendirilmiş kompozitlerden modellenirken en iç tabakaları Alüminyum (Al2024-T3) malzemeden oluşturulmuştur. Sayısal burkulma davranışı sonlu elemanlar yazılımı ANSYS kullanılarak hesaplanmıştır. Sinyal-Gürültü oran analizi burkulma davranışı üzerinde plakaların optimal seviyelerini ve fiber oryantasyon açılarının etkilerini karar vermek için kullanıldı. Burkulma yanıtları üzerinde önemli etkiye sahip olan kontrol faktörlerini belirlemek için \% 95 güven seviyesinde varyans analizi uygulandı.

Anahtar Kelimeler: Burkulma, Hibrit Kompozit, Sonlu Elemanlar, Taguchi Metodu. 


\section{INTRODUCTION}

Laminated composite plates are used in many areas due to their low density, corrosion resistance and high strength properties compared to a lot of metal materials. Because of these superior properties, laminated composite plates and beams were used for many analyses such as buckling [1], free vibration [2], deflection [3], buckling temperature [4], twisting angle [5], thermal stress [6] etc. Buckling behavior of laminated composite plates is a vital issue and it is important to focus on the buckling phenomenon. There are many numerical and analytical studies including critical buckling load of laminated composites and the impacts of factors such as fiber orientation angle, sum of number of plies, plate sizes, boundary conditions, [7, 8], size and position of delamination [9-13]. In literature, composite structures made of glass-epoxy, boronepoxy, carbon-epoxy were widely utilized. Heidari-Rarani et al. [14] investigated the influence of ply stacking sequence for theoretical and experimental buckling analysis of laminated composites made of Eglass/epoxy. Jeyaprakash et al. [15] examined of the buckling behavior of carbon epoxy fiber composite under buckling load using experimental and numerical methods. Erdem et al. [16] analyzed the postbuckling behavior of composite plates made of carbon fiber epoxy and they used ANSYS software for numerical approach. Guo et al. [17] examined the buckling and post-buckling behavior of a composite made of carbon/epoxy and C-section structure. Sudhirsastry et al. [18] analyzed the buckling behavior of thin wall stiffened composite panels and they used finite element approach. Also, some optimization methods for composites were used such as genetic algorithm [19-22] and the modified feasible direction [23, 24]. In this study, Taguchi method was used to optimize the composite plates and fiber orientation angles. This method decreases the test numbers. Also, hybrid laminated composite plates have been used for different analyses in many areas. Yalçın and Ergene [25] determined the effect of the crack placed in different areas within the hybrid composite material with different fiber angles on the mechanical behavior by finite element analysis. Akbulut et al. [28] presented a study including non-linear optimization methods on composite structures under vibration and buckling loads. In analysis, laminate hybrid composite materials reinforced with glass-epoxy, boron-epoxy, carbon-epoxy, glass-boron-carbon-epoxy were used. It is seen from mentioned literature review that there are several studies including various analyses of laminated composite and hybrid composite plates. In this study, critical buckling load of hybrid composite plates with three layers was analyzed using numerical and statistical methods according to finite element method and Taguchi L9 orthogonal array consisting of two control factors with three levels.

\section{MATERIALS AND METHODS}

In buckling analysis, hybrid composite plates made from metal material and fiber reinforced composite were used. The plates have three laminates. The outermost layers of the plates were made by composite materials such as glass-epoxy, boron-epoxy, carbon-epoxy, glass-boron-carbon-epoxy. Innermost layer of plates was designed using Aluminum material (A12024-T3). Mechanical properties of metal and composite materials were illustrated in Table 1.

Table 1. Material properties [25]

\begin{tabular}{cccccccccc}
\hline Materials & $\begin{array}{c}\mathrm{E}_{\mathrm{x}} \\
(\mathrm{GPa})\end{array}$ & $\begin{array}{c}\mathrm{E}_{\mathrm{y}} \\
(\mathrm{GPa})\end{array}$ & $\begin{array}{c}\mathrm{E}_{\mathrm{z}} \\
(\mathrm{GPa})\end{array}$ & $\mathrm{v}_{\mathrm{xy}}$ & $\mathrm{v}_{\mathrm{xz}}$ & $\mathrm{v}_{\mathrm{yz}}$ & $\begin{array}{c}\mathrm{G}_{\mathrm{xy}} \\
(\mathrm{GPa})\end{array}$ & $\begin{array}{c}\mathrm{G}_{\mathrm{xz}} \\
(\mathrm{GPa})\end{array}$ & $\begin{array}{c}\mathrm{G}_{\mathrm{yz}} \\
(\mathrm{GPa})\end{array}$ \\
\hline Al2024-T3 & 72.4 & 72.4 & 72.4 & 0.33 & 0.33 & 0.33 & 27.6 & 27.6 & 27.6 \\
Glass/Epoxy & 38.5 & 9.35 & 9.35 & 0.22 & 0.05 & 0.05 & 3.47 & 3.47 & 3.47 \\
Boron/Epoxy & 202.4 & 9.87 & 9.87 & 0.25 & 0.01 & 0.01 & 3.65 & 3.65 & 3.65 \\
Carbon/Epoxy & 112.5 & 9.77 & 9.77 & 0.25 & 0.02 & 0.02 & 3.29 & 3.29 & 3.29 \\
\hline
\end{tabular}

Numerical buckling analyses for the first mode in ANSYS software were conducted using Taguchi L9 orthogonal array with two control factors and three levels. The control factors were selected as hybrid composite plates and fiber orientation angles. The levels of the first control factor were assumed as 
Glass/Epoxy-Al- Glass/Epoxy, Boron/Epoxy-Al- Boron/Epoxy, and Carbon/Epoxy-Al- Carbon/Epoxy whereas the levels of the second control factor were determined as 0,45 , and 90 degrees. The control factors and levels were tabulated in Table 2.

Table 2. Control factors and levels

\begin{tabular}{|c|c|c|c|c|}
\hline \multirow{2}{*}{$\begin{array}{l}\text { Control } \\
\text { Factors }\end{array}$} & \multirow{2}{*}{ Symbol } & \multicolumn{3}{|c|}{ Levels } \\
\hline & & Level 1 & Level 2 & Level 3 \\
\hline $\begin{array}{l}\text { Plate } \\
\text { Type }\end{array}$ & A & $\begin{array}{c}\text { Glass/Epoxy-Al- } \\
\text { Glass/Epoxy }\end{array}$ & $\begin{array}{c}\text { Boron/Epoxy-Al- } \\
\text { Boron/Epoxy }\end{array}$ & $\begin{array}{c}\text { Carbon/Epoxy-Al- } \\
\text { Carbon/Epoxy }\end{array}$ \\
\hline $\begin{array}{l}\text { Fiber } \\
\text { Angle }\end{array}$ & B & [0] & [45] & [90] \\
\hline
\end{tabular}

To obtain the maximum critical buckling load of laminated hybrid composite plates, "larger is better" characteristic was used for analysis of $\mathrm{S} / \mathrm{N}$ ratio. The characteristic was given in Equation 1 [26].

$$
(\mathrm{S} / \mathrm{N})_{\mathrm{HB}}=-10 \cdot \log \left(\mathrm{n}^{-1} \sum_{\mathrm{i}=1}^{\mathrm{n}}\left(\mathrm{y}_{\mathrm{i}}^{2}\right)^{-1}\right)
$$

in which, $n$ is the number of numerical calculations in a trial and $y_{i}$ means $i^{\text {th }}$ data examined. Statistical analyses were performed in Minitab 15 software.

\section{FINITE ELEMENT ANALYSIS}

Finite element analyses for critical buckling load were carried out using ANSYS software. In analyses, SHELL281 element type was used. Cantilever hybrid composite plate have dimensions $100 \mathrm{~mm}$ (length) $\times$ $100 \mathrm{~mm}$ (width) $\times 1.5$ (thickness). Thickness of each lamina has $0.5 \mathrm{~mm}$. This element consists of 8 nodes which has 6 degrees of freedom for each node: translations for the $\mathrm{x}, \mathrm{y}$, and $\mathrm{z}$ axes, and rotations regarding the $\mathrm{x}, \mathrm{y}$, and $\mathrm{z}$-axes [27]. Hybrid composite plates with three layers was modelled as cantilever boundary condition. Block lanczos eigenvalue extraction method was utilized for buckling analysis and this method can be offered for large symmetric eigenvalue solutions. The outermost layers of the plates were created using fiber reinforced composite materials with different fiber orientation angles such as $0^{\circ}, 45^{\circ}$, and $90^{\circ}$. Fiber orientation angles of laminated hybrid composite plates were illustrated in Figure 1.

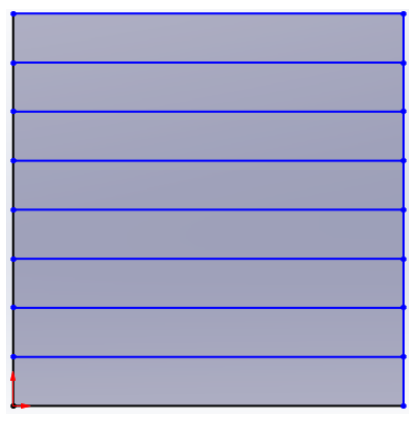

a) $0^{\circ}$

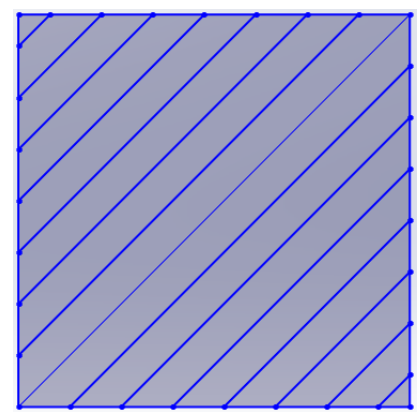

b) $45^{\circ}$

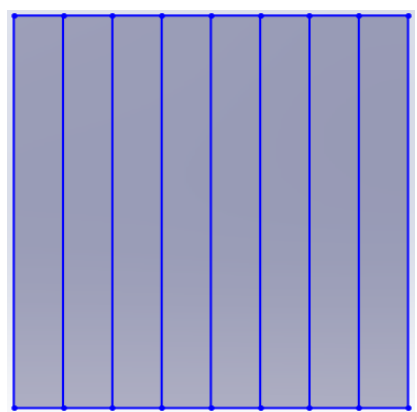

c) $90^{\circ}$

Figure 1. Fiber orientation angles of composite plates

\section{RESULTS AND DISCUSSIONS}

The aim of this study is to analyze the effect of the laminated hybrid composite plates and fiber orientation angles on the critical buckling load numerically and statistically. Finite element results and their S/N ratio data were demonstrated in Table 3. 
Table 3. Results based on L9 orthogonal array

\begin{tabular}{|c|c|c|c|c|c|}
\hline \multirow{3}{*}{ Run } & \multirow{3}{*}{ Designation } & \multirow{2}{*}{\multicolumn{2}{|c|}{ Control Factors }} & \multicolumn{2}{|c|}{ Results } \\
\hline & & & & \multirow{2}{*}{$\begin{array}{c}\text { Critical Buckling } \\
\mathrm{P}_{\text {cr }}(\mathrm{N})\end{array}$} & \multirow{2}{*}{$\begin{array}{c}\text { S/N ratio } \\
\eta(\mathrm{dB})\end{array}$} \\
\hline & & Hybrid Composite Plates & Fiber Angle & & \\
\hline 1 & $\mathrm{~A}_{1} \mathrm{~B}_{1}$ & Glass/Epoxy-Al-Glass/Epoxy & [0] & 279.335 & 48.9225 \\
\hline 2 & $\mathrm{~A}_{1} \mathrm{~B}_{2}$ & Glass/Epoxy-Al-Glass/Epoxy & [45] & 160.458 & 44.1072 \\
\hline 3 & $\mathrm{~A}_{1} \mathrm{~B}_{3}$ & Glass/Epoxy-Al-Glass/Epoxy & [90] & 83.2541 & 38.4081 \\
\hline 4 & $\mathrm{~A}_{2} \mathrm{~B}_{1}$ & Boron/Epoxy-Al-Boron/Epoxy & [0] & 1373.810 & 62.7585 \\
\hline 5 & $\mathrm{~A}_{2} \mathrm{~B}_{2}$ & Boron/Epoxy-Al-Boron/Epoxy & [45] & 157.941 & 43.9699 \\
\hline 6 & $\mathrm{~A}_{2} \mathrm{~B}_{3}$ & Boron/Epoxy-Al-Boron/Epoxy & [90] & 86.7477 & 38.7652 \\
\hline 7 & $A_{3} B_{1}$ & Carbon/Epoxy-Al-Carbon/Epoxy & [0] & 774.189 & 57.7769 \\
\hline 8 & $\mathrm{~A}_{3} \mathrm{~B}_{2}$ & Carbon/Epoxy-Al-Carbon/Epoxy & [45] & 133.188 & 42.4893 \\
\hline \multirow[t]{2}{*}{9} & $\mathrm{~A}_{3} \mathrm{~B}_{3}$ & Carbon/Epoxy-Al-Carbon/Epoxy & [90] & 86.054 & 38.6954 \\
\hline & & Overall Mean $\left(\overline{\mathrm{T}_{P_{C R}}}\right)$ & & 348.331 & - \\
\hline
\end{tabular}

Numerical analyses were carried out in ANSYS software and images of the results obtained were shown in Figure 2. As can be seen from Figure 2, the maximum affected edges were determined as the edge subjected to load for cantilever plates. This finding is in agreement with study consisting of deflection [3] analysis of laminated composite plates.

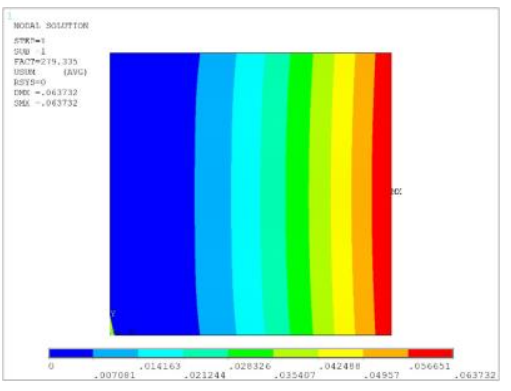

1. Analysis

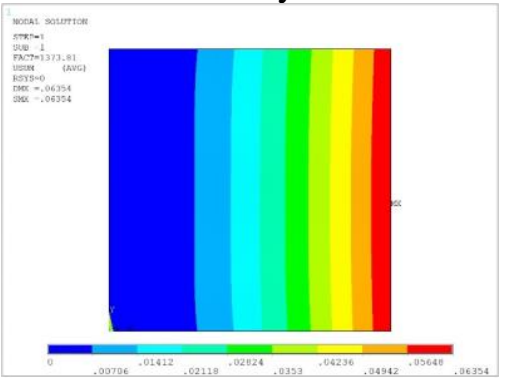

4. Analysis

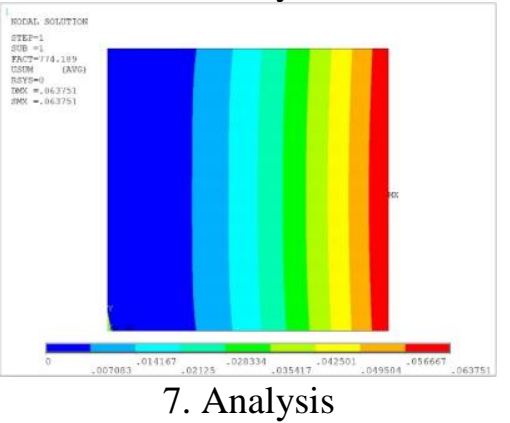

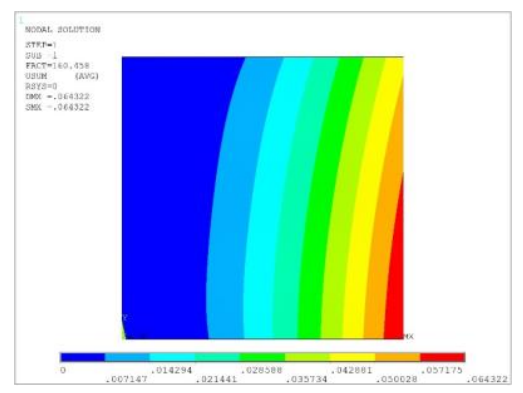

2. Analysis

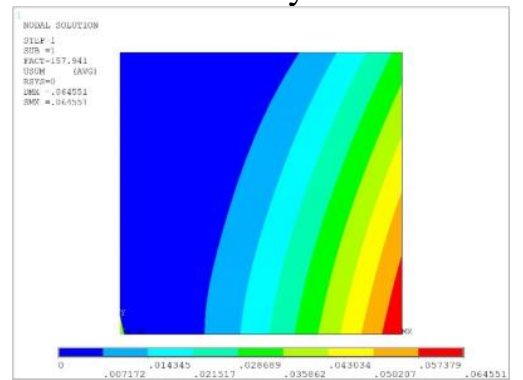

5. Analysis

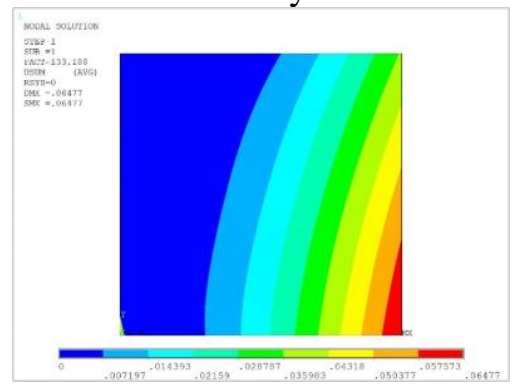

8. Analysis

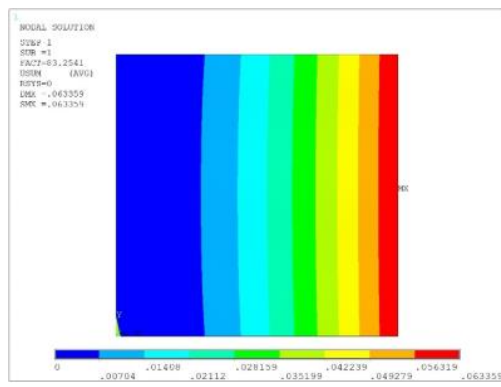

3. Analysis

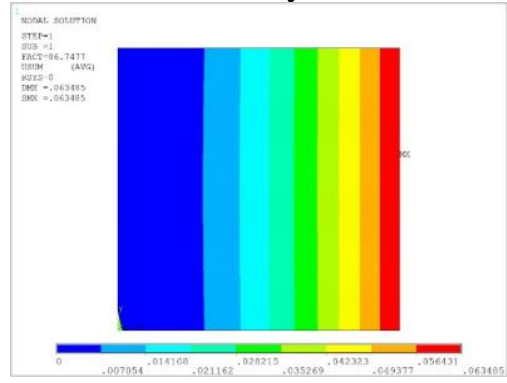

6. Analysis

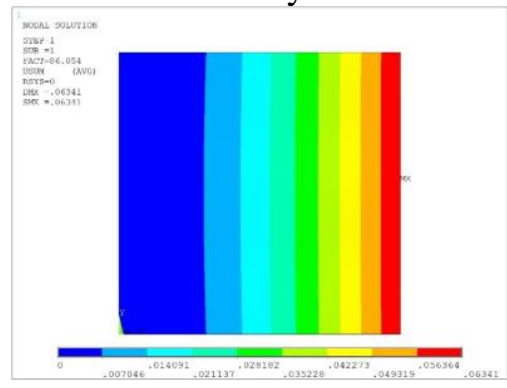

9. Analysis

Figure 2. ANSYS results of buckling behavior for the first mode 


\subsection{Impact of Control Factors}

Analysis of S/N ratio was carried out to analyze the optimal levels of hybrid composite types and fiber orientation angles. The average values of $\mathrm{S} / \mathrm{N}$ ratio and mean for each level of each control factor were calculated in Minitab statistical software and these results were demonstrated in Table 4.

Table 4. Response table for buckling load

\begin{tabular}{ccccc}
\hline \multirow{2}{*}{ Level } & \multicolumn{2}{c}{ S/N ratio $(\mathrm{dB})$} & \multicolumn{2}{c}{ Mean $(\mathrm{N})$} \\
\cline { 2 - 5 } & $\mathrm{A}$ & $\mathrm{B}$ & $\mathrm{A}$ & $\mathrm{B}$ \\
\hline 1 & 43.81 & 56.49 & 174.35 & 809.11 \\
2 & 48.50 & 43.52 & 539.50 & 150.53 \\
3 & 46.32 & 38.62 & 331.14 & 85.35 \\
Delta & 4.69 & 17.86 & 365.15 & 723.76 \\
Rank & 2 & 1 & 2 & 1 \\
\hline
\end{tabular}

It can be seen from Table 4 that the optimal result for buckling analysis was obtained using hybrid composite plate at the second level and fiber orientation angle at the first level. In other word, the maximum critical buckling load was calculated using Boron/Epoxy-Al-Boron/Epoxy plate made of fiber orientation angle with 0 degree. To see the effect of each control factor, main effect plot was plotted using the average data of $\mathrm{S} / \mathrm{N}$ ratio based on numerical results. The plot was shown in Figure 3.

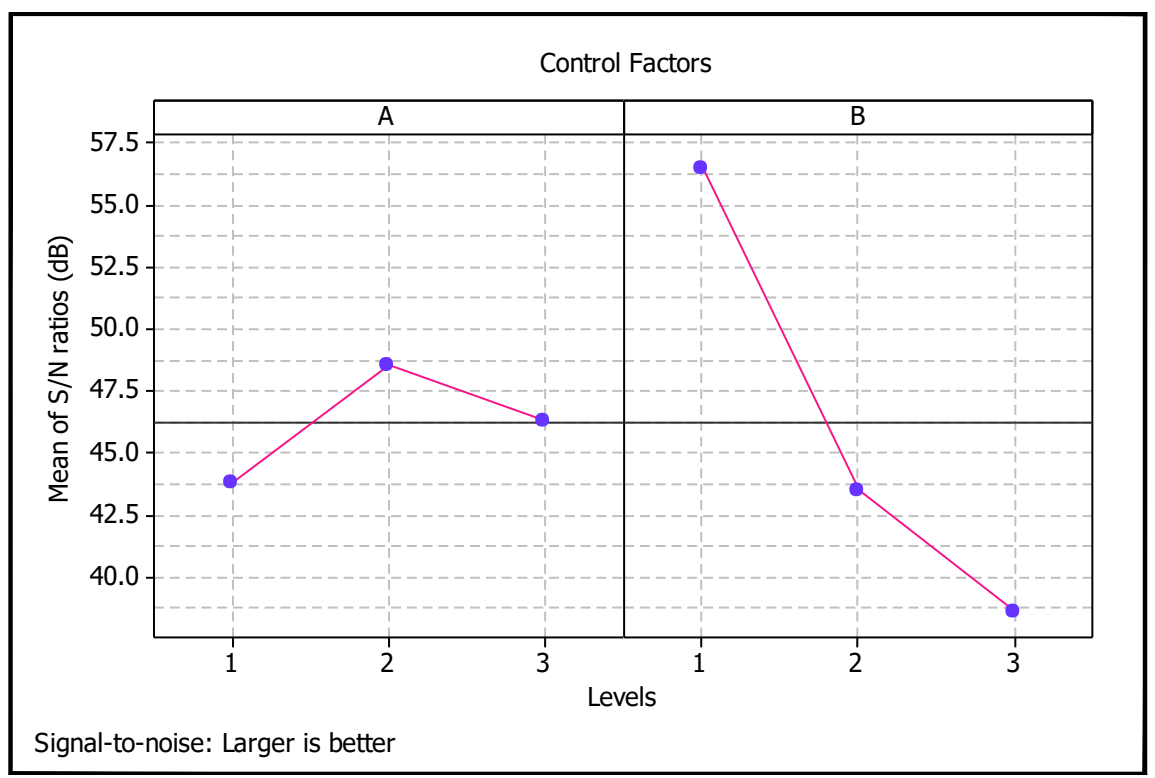

Figure 3. Main effect of control factors for $\mathrm{S} / \mathrm{N}$ ratio

According to Figure 3, the critical buckling load of hybrid composite plate made of Boron/Epoxy-AlBoron/Epoxy is higher than that of plates designed from Glass/Epoxy-Al-Glass/Epoxy and Carbon/EpoxyAl-Carbon/Epoxy. In other word, the maximum critical buckling load for the first mode are obtained using plates made of Boron/Epoxy-Al-Boron/Epoxy, Carbon/Epoxy-Al-Carbon/Epoxy, and Glass/Epoxy-AlGlass/Epoxy, respectively. This situation can be explained by the high mechanical properties of hybrid composite plates. The increase of the mechanical property such as elasticity modules can cause the increase of critical buckling of the plates. Also, Figure 3 shows that the increase of fiber orientation angle from 0 to 90 in degree leads to the decrease of the critical buckling load of fiber reinforced composite. This finding 
is in agreement with studies including buckling [1], free vibration [2], and deflection [3] analyses of fiber reinforced composites.

\subsection{Analysis of Variance}

Analysis of Variance (ANOVA) is a statistical method, and it was carried out to determine the effect ratio and significant levels of control factors such as laminated hybrid composite plates and fiber orientation angles on the critical buckling load of plates. ANOVA was performed at $\% 95$ confidence level and result obtained was tabled in Table 5.

Table 5. ANOVA result for buckling load

\begin{tabular}{cccccccc}
\hline Source & DF & Seq SS & Adj SS & Adj MS & F & P & \% Effect \\
\hline A & 2 & 201332 & 201332 & 100666 & 1.01 & 0.442 & 12.88 \\
B & 2 & 961806 & 961806 & 480903 & 4.81 & 0.086 & 61.53 \\
Error & 4 & 399897 & 399897 & 99974 & & & 25.59 \\
Total & 8 & 1563035 & & & & & 100 \\
\hline
\end{tabular}

As can be seen from Table 5, the maximum effects of control factors on buckling load of hybrid composite plates were determined as fiber orientation angle with $61.53 \%$ and type of hybrid composite plates with $12.88 \%$, respectively. Hybrid composite types and fiber orientation angles for $95 \%$ confidence level have a meaningless effect on the buckling analysis since $P$ value is smaller than 0.05 value.

\subsection{Estimation of Optimal Critical Buckling Load}

Estimated critical buckling load for the first mode was calculated using overall data at the optimal level for each control factor. Estimated critical buckling load based on Taguchi method may be solved using Equation 2 [26].

$$
\mu_{P_{C R}}=\overline{\mathrm{A}_{2}}+\overline{\mathrm{B}_{1}}-\overline{\mathrm{T}_{P_{C R}}}
$$

where, $\overline{\mathrm{A}_{2}}=539.50$ and $\overline{\mathrm{B}_{1}}=809.11$ show the average data of the critical buckling load for the first mode of hybrid composite plate at the second level and fiber orientation angle at the first level. In addition, $\overline{\mathrm{T}_{P_{C R}}}$ is average mean for Taguchi's L9 orthogonal array and it was computed as $348.331 \mathrm{~N}$. Thus $\mu_{P_{C R}}$ was found as $1000.28 \mathrm{~N}$.

\section{CONCLUSION}

The purpose of this numerical and statistical study is to calculate the critical buckling load of hybrid composite plates with three layers. Laminated hybrid composite plates were constructed using glass-epoxy, boron-epoxy, carbon-epoxy, and metal. The outermost layers of the plates were formed using fiber reinforced fiber composite materials whereas the innermost layer of plates was generated using Aluminum material (A12024-T3). Finite element buckling analyses was performed using finite element software ANSYS. Analysis of signal-to-noise ratio was employed to choose the effects and the best levels of the plates and their fiber orientation angles under buckling load. Analysis of variance was utilized to show the control factors which have substantial influence on the buckling behavior. According to this study, the critical buckling load of hybrid composite plate made from Boron/Epoxy-Al-Boron/Epoxy is higher than that of plates constructed from Glass/Epoxy-Al-Glass/Epoxy and Carbon/Epoxy-Al-Carbon/Epoxy. The increase of fiber orientation angle from 0 to 90 in degree causes a decrease on the critical buckling load. The maximum impacts of control factors on buckling load of hybrid composite plates were defined as fiber orientation angle with $61.53 \%$ and type of hybrid composite plates with $12.88 \%$. Prediction of optimal critical buckling load was found as $1000.28 \mathrm{~N}$ in accordance with Taguchi method. Also, the maximum affected edges were defined as the edge subjected to load for cantilever plates. 


\section{REFERANSLAR}

[1] Evran, S., (2020). "Numerical and statistical buckling analysis of laminated composite plates with functionally graded fiber orientation angles", Polymers and Polymer Composites, 28, 7, 502-512.

[2] Evran, S., (2020). "Experimental and statistical free vibration analyses of laminated composite beams with functionally graded fiber orientation angles", Polymers and Polymer Composites, 28, 7, 513-520.

[3] Evran, S., (2020). "Investigation of effects of fiber orientation angles on deflection behavior of cantilever laminated composite square plates", Politeknik Dergisi, 23, 3, 633-639.

[4] Evran, S., (2020). "Buckling temperature analysis of laminated composite plates with circular and semicircular holes", Eskişehir Technical University Journal of Science and Technology A-Applied Sciences and Engineering, 21, 1, 173-181.

[5] Evran, S., (2019). "Twisting angle analysis of laminated composite plates using numerical and statistical methods", Süleyman Demirel Üniversitesi Fen Bilimleri Enstitüsü Dergisi, 23, 2, 466-471.

[6] Evran, S., (2019). "Finite element analysis of thermal stress of laminated composite plates using taguchi method", Manas Journal of Engineering, 7, 2, 121-125.

[7] Tang, Y. and Wang, X., (2011). "Buckling of symmetrically laminated rectangular plates under parabolic edge compressions", International Journal of Mechanical Sciences, 53, 2, 91-97.

[8] Özben, T., (2009). "Analysis of critical buckling load of laminated composites plate with different boundary conditions using fem and analytical methods", Computational Materials Science, 45, 4, 1006-1015.

[9] Pekbey, Y. and Sayman, O., (2006). "A numerical and experimental investigation of critical buckling load of rectangular laminated composite plates with strip delamination", Journal of Reinforced Plastics and Composites, 25, 7, 685-697.

[10] Arman, Y., Zor, M. and Aksoy, S., (2006). "Determination of critical delamination diameter of laminated composite plates under buckling loads", Composites Science and Technology, 66, 15, 2945-2953.

[11] Lee, S.-Y. and Park, D.-Y., (2007). "Buckling analysis of laminated composite plates containing delaminations using the enhanced assumed strain solid element", International Journal of Solids and Structures, 44, 24, 80068027.

[12] Al Qablan, H., Katkhuda, H. and Dwairi, H., (2009). "Assessment of the buckling behavior of square composite plates with circular cutout subjected to in-plane shear", Jordan Journal of Civil Engineering, 3, 184-195.

[13] C W, Y., Chai, G. B. and Parlapalli, M. S. R., (2008). "Effect of flexural stiffness estimates on the buckling load of delaminated composite beams", Proceedings of the Institution of Mechanical Engineers, Part L: Journal of Materials: Design and Applications, 222, 2, 91-102.

[14] Heidari-Rarani, M., Khalkhali-Sharifi, S. S. and Shokrieh, M. M., (2014). "Effect of ply stacking sequence on buckling behavior of e-glass/epoxy laminated composites", Computational Materials Science, 89, 89-96.

[15] Jeyaprakash, P., Prabhakaran, V. and Devaraju, A., (2018). "Experimental and numerical analysis of carbon epoxy fibre composite under buckling load", Materials Today: Proceedings, 5, 6, Part 2, 14526-14530.

[16] Erdem, S., Kaman, M. O. and Gur, M., (2019). "Post-buckling behavior of carbon fiber epoxy composite plates", Journal of Mechanical Science and Technology, 33, 4, 1723-1730.

[17] Guo, S., Li, D., Zhang, X. and Xiang, J., (2014). "Buckling and post-buckling of a composite c-section with cutout and flange reinforcement", Composites Part B: Engineering, 60, 119-124.

[18] Sudhirsastry, Y. B., Budarapu, P. R., Madhavi, N. and Krishna, Y., (2015). "Buckling analysis of thin wall stiffened composite panels", Computational Materials Science, 96, 459-471.

[19] Karakaya, Ş. and Soykasap, Ö., (2011). "Natural frequency and buckling optimization of laminated hybrid composite plates using genetic algorithm and simulated annealing", Structural and Multidisciplinary Optimization, 43, 1, 61-72.

[20] Walker, M. and Smith, R. E., (2003). "A technique for the multiobjective optimisation of laminated composite structures using genetic algorithms and finite element analysis", Composite Structures, 62, 1, 123-128.

[21] Park, J. H., Hwang, J. H., Lee, C. S. and Hwang, W., (2001). "Stacking sequence design of composite laminates for maximum strength using genetic algorithms", Composite Structures, 52, 2, 217-231.

[22] Riche, R. L. and Haftka, R. T., (1993). "Optimization of laminate stacking sequence for buckling load maximization by genetic algorithm", AIAA Journal, 31, 5, 951-956.

[23] Topal, U. and Uzman, Ü., (2007). "Optimum design of laminated composite plates to maximize buckling load using mfd method", Thin-Walled Structures, 45, 7, 660-669.

[24] Topal, U. and Uzman, Ü., (2009). "Effects of nonuniform boundary conditions on the buckling load optimization of laminated composite plates", Materials \& Design, 30, 3, 710-717. 
[25] Yalçın, B. and Ergene, B., (2018). "Analyzing the effect of crack in different hybrid composite materials on mechanical behaviors", Pamukkale Univ Muh Bilim Derg, 24, 4, 616-625.

[26] Ross, P. J. (1996). Taguchi techniques for quality engineering. McGraw-Hill International Editions, 2nd Edition, New York, USA.

[27] ANSYS Help, Version 13. (ANSYS Inc, Canonsburg, PA, USA).

[28] Akbulut, M., Sarac, A. and Ertas, A.H., (2020). "An investigation of non-linear optimization methods on composite structures under vibration and buckling loads", Advances in Computational Design, 5, 3, 209-231. 